\title{
TATĂL EI, LUCIAN BLAGA. RECONSTITUIRI BIOGRAFICE
}

\section{Alexandra Ana-Maria Diaconița, masterandă} Facultății de Litere, Universitatea „,Alexandru Ioan Cuza”, Iași

Abstract: The volume Tatăl meu, Lucian Blaga has a double meaning: first of all, Dorli Blaga intends to shape the writer's portrait and, above all, the man Lucian Blaga himself, for whom the act of creation becomes a refuge. Secondly, it creates an autobiographical work, appealing to her own memories and exposing her own opinion regarding the writers and political unions of the 20th century. This volume clearly shows the daughter's duty to defend her father's name. This essay Tatăl ei, Lucian Blaga. Reconstituiri biografice presents the impediments ecountered by Lucian Blaga in his literary and political career, but also his image in the intimate position as a parent and husband. The sacrifices accomplished on behalf of his family, the fear of having his work plagiarised and the strength to bear the injustices of the Romanian state are just some details from Lucian Blaga's life, presented by his daughter or revealed by the writer himself in his correspondence.

Key-words: personality, diary, family memories, letters, creation

\section{„...dar ceea ce voi scrie e amintirea mea"}

Lucian Blaga încearcă prin scrierile cu caracter memorialistic să stăpânească efemerul; în Elanul insulei, scriitorul susține că ,plăcerea de a scrie memorii consistă în a reorganiza în spiritul libertătii ceea ce destinul a organizat odată cu constrângerea împrejurărilor" (Blaga, 1977: 108) ceea ce prezintă și viziunea lucrării de față. Memorialistica lui Lucian Blaga indică o naturalețe a scrierii, care-i lipsește, de altfel, lui Dorli Blaga sub expunerea căreia se descoperă amprentele unei datorii filiale, necesare în a clarifica postura și imaginea tatălui în contemporaneitate. Astfel, în Tatăl meu, Lucian Blaga, Dorli Blaga evocă un tip de libertate ce se bazează pe aspecte private ale vieții de familie, care relaționează cu noțiunea de adevăr , de elucidare a misterului în care profilul intelectualului Lucian Blaga se situează. Dorli Blaga conturează secvențial posturi inedite ale tatălui, ale soțului, scriitorului și diplomatului Lucian Blaga, concentrându-se, de altfel, şi pe unele evenimente private, ce indică povara purtării unui nume atât de cunoscut.

Încadrat în memorialistica actuală, volumul pare a întregi colecția de dezvăluiri asupra personalității marelui poet și filosof, infirmând, aşadar, unele publicații ale vremurilor de restriște. Deși, în aparență, acesta pare a fi principalul motiv al apariției cărții, autoarea susține că: „povestind despre

\footnotetext{
${ }^{1}$ Dorli Blaga, Tatăl meu, Lucian Blaga, Editura Humanitas, București, 2015, p 9.
} 
Tata, Mama, Tudor, copii, prieteni (adevărați și trădători), m-am salvat dintr-o stare care, după studiile diferitelor Dosare de Securitate și mai ales după reacțiile, ciudat de deplasate, ale unor prieteni, privind demersul meu, putea deveni depresivă" (Dorli Blaga, 2015: 128). Există, astfel, o dublă valență a acestui volum; Dorli Blaga intenționează a se elibera și îndepărta de pseudorealitatea prescrisă de cei situați împotriva concepțiilor filosofice și literare ale propriului Tată, oferind, astfel, şi o replică a activităţii şi, implicit, a personalității lui Lucian Blaga, individualizându-l. Așadar, în Tatăl meu, Lucian Blaga, autoarea evidențiază relațiile de familie, conturând portretul scriitorului și, mai ales, al omului Lucian Blaga, pentru care opera devine refugiu, iar crearea ei un mod de viață și nu doar o achiziționare de informații. Totodată, în volum sunt condensate mai multe documente reprezentative în conturarea unor etape din viața scriitorului; în Corespondență de familie comentată sunt identificate scrisorile referitoare atât la viaţa privată cât și politică a scriitorului, pe când în subcapitolul Tatăl meu supravegheat de Securitate din Oprimarea, autoarea se prezintă nu doar în calitate de fiică a unuia dintre cei mai importanţi scriitori ai secolului al XX-lea, ci și în calitate de soție și mamă posesoare a unei puternice înclinații către sacrificiu, aidoma tatălui ei.

Alternanța apelativului Tata-Lucian Blaga din interiorul cărții se datorează separării a două ipostaze: cea parentală și cea profesională. Totodată, utilizarea apelativelor sugerează și relația dintre relatările vieții private, generate de destăinuiri și rememorări din copilărie: „A intrat Tata, i-am văzut chipul deasupra patului. Era serios, tăcut, nu zâmbea, mă privea. Și a făcut un gest de dojană, cu degetul arătător, spunând: «Dorli, Dorli!» Atât. Am aflat mai târziu că refuzasem să dorm" (Dorli Blaga, 2015: 12) şi evenimentele din viața publică, în cadrul cărora autoarea omite până și prenumele scriitorului, reliefând atât privilegiul de a aparține familiei Blaga, cât și accentuarea importanței acestui nume în istoria literară și filosofică. Prin intermediul lui Dorli Blaga, se încearcă, astfel, o revalorizare a statutului și a numelui Blaga; aceasta respinge până și oferta președintelui Academiei RSR, Miron Nicolescu, de a contextualiza creația tatălui, bazându-se pe o serie de argumente care indică încercarea apărării unui nume atât de controversat, precum cel de Blaga: „refuzul meu categoric de a oferi manuscrise din lucrările lui Blaga de filosofie, lucrări pentru care a fost scos din Academie, lucrări care au fost prezentate negativ și în exegeze publicate de Academia RSR. De asemenea mi-am spus părerea despre faptul că, atunci când vin «străini», subit Blaga este bun pentru a fi expus” (Ibidem: 69).

Lucrarea de față, raportată la personalitatea lui Lucian Blaga, urmărește reevaluarea unor piloni biografici prin intermediul volumului memorialistic al lui Dorli Blaga, dar și al Jurnalului Corneliei Brediceanu și, implicit, al Corespondenței scriitorului, accentuându-se atât diferite aspecte

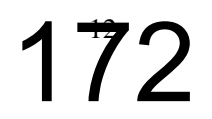


familiale ori modalități de generare a actului creației, cât și calitatea de om politic a lui Lucian Blaga, valorificată atât prin vizatul Premiu Nobel, cât și prin distincția enunțată de Regele Carol al II-lea în vederea desemnării acestuia drept membru al Academiei Române. Totodată, lucrarea Tatăl ei, Lucian Blaga. Reconstituiri biografice se compune din trei perspective diferite în realizarea portretului lui Lucian Blaga: perspectiva fiicei asupra părintelui, evidențiată prin aspecte ale vieții private-ipostaza tatălui și frământările sale cauzate de opresiunile regimului; perspectiva în ton obiectiv a criticului și istoricului literar Ion Bălu și perspectiva lui Blaga însuși, asumată în corespondență, prin intermediul căreia se realizează un autoportret al scriitorului exilat în propria țară.

\section{„Tata spunea că ei sunt o monadă"2}

Lucian Blaga apare sub ipostaza îndrăgostitului, cele mai multe din scrisorile cuprinse în volumul Corespondență, expunând vulnerabilitatea acestuia în fața iubirii. Totodată, apelativele pe care Blaga le folosește în formulele de adresare: Sfinxule dragă, Mea Gaor, O Gari, Mireasa mea, Stăpâna mea, Adorato, Sanctuarul meu, Edera-iubito, Minunea mea, Mult iubito trădează un cadru intim, deja stabilit între tânărul Blaga și Cornelia Brediceanu și accentuat odată cu destăinuirile frenetice: ,te doresc nebun. Așai de frumos să fii tânăr. Mă scald în daruri tinere și-n gânduri tinere și-n vreri tinere. Bărbăția îmi bate la ușă - și ciocănitoarea la fereastră. Voi fi vr-odată bătrân? Nu cred" (Blaga, 1989: 126). Datorăm aceste formulări și prezenţei unui eu exacerbat în a cunoaște dragostea. Erotismul din scrisorile lui Lucian Blaga constituie, prin frânturile expuse, un profil al scriitorului a cărui efervescență a spiritului și, totodată, îmbrățișare a existențialului se regăsesc și în primele două volume de poezii, Poemele luminii și Pașii profetului: „Cum singurătatea fără tine se suportă greu, nu poți știi ziua și ceasul când voi năvăli direct subt plapoma ta sărată - prefăcut în ecstatic steag fâlfâitor" (Dorli Blaga, 2015: 273). Totodată, neoromanticul Blaga formulează în scrisorile adresate iubitei, aserțiuni cu un caracter mult mai intens, sugerându-se, astfel, baza solidă a relaţiei celor doi: „simt totuşi ceva precis: te simt pe Tine cum îmi pulsezi în sânge. Aș vorbi, de renaștere, transformare, transfigurațiune, dacă nu ți-ar părea sentimental. În orice caz, în istoria mea individuală s-a început epoca reformațiunii” (Blaga, 1989: 87). Așadar, aparențele se dispersează, iar în scrisori Blaga este definiția sentimentalului, a îndrăgostitului incurabil: „ca să știi că exist - cu cerul deasupra, cu mormintele jos, și cu tine la mijloc în ce e viața" (Dorli Blaga, 2015: 217), care asociază, în unele situații, absența iubitei cu o omniprezență a morții: „Te aștept cu siguranță pe duminică. Altfel mor" (Dorli Blaga, 2015: 268).

\footnotetext{
${ }^{2}$ Cornelia Brediceanu-Blaga, Jurnale, (Introducere), Editura Humanitas, București, 2016, p. 9.
}

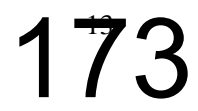


Dorli Blaga reia declarația tatălui cu privire la termenul de monadă, în cele două apariții: Tatăl meu, Lucian Blaga și în introducerea Jurnalelor mamei sale. Odată cu apariția muzelor în viața scriitorului, monada preia un caracter artificial, despre care afirmă și Dorli Blaga într-un interviu inclus în Addenda volumului Corneliei Brediceanu: „Eu l-am înțeles. Adică, de exemplu, aveam vreo doisprezece ani când a apărut Domnița efectiv în viața lui şi am realizat, fără să vorbesc, că Mama era întristată, dar se stăpânea" (Brediceanu, 2016: 167). Ion Bălu, în cel de-al doilea volum dedicat Vieții lui Lucian Blaga, analizează aspectele care au condus la criza creatoare a scriitorului, intuind, astfel și motivul pentru care acesta apelează la inspirația oferită de muze, conturând, totodată, și statutul de om al acestuia: „Afecțiunea soției, ce-i înconjura cu un zid creația nu i se părea suficientă; se obișnuise cu ea și i se părea normală de la un timp, probabil nici nu o mai sesiza. [...] Odată cu atenuarea pasiunii iniţiale, soția nu-i mai inspira nicio poezie de dragoste" (Bălu, 1996: 425). Însăşi Dorli Blaga - având perspectiva părtinitoare - susține că Ion Bălu accentuează unele detalii cu scopul captării interesului cititorului, criticul literar oferind evenimentelor o notă senzaţională. În cadrul familial, statut de scriitor emerit al tatălui nu împiedică realizarea profesională a fiicei; Dorli Blaga, făcând referire la comportamentul lui Lucian Blaga și, implicit, la receptarea poziției acestuia în literatură, susține că: ,în cazul unui părinte cum a fost Tatăl meu, pentru copii nu ar trebui să se pună problema competiției cu părintele. Pentru mine a fost ușor, eram fată și mă puteam realiza, în condiții relativ normale, pe alte planuri” (Dorli Blaga, 2015: 10).

\section{Personalitatea artistului în vremuri de cumpănă}

Registrul epistolelor se schimbă treptat, devenind mult mai concentrat în prezentarea unor evenimente și știri cotidiene. Acest fapt poate fi analizat atât din prisma depășirii etapei îndrăgostitului și pășirii în evenimențial, Lucian Blaga fiind însărcinat, totodată, și cu atribuții diplomatice, cât și din prisma apariției, în cea de-a doua jumătate a secolului XX, a cenzurii. Pe lângă declarațiile de dragoste, vasta corespondență reliefează şi concepții asupra socialului, pe care Lucian Blaga - tânărul idealist - reușește a le expune ca probleme ale sinelui: „,ăd cu ochi trupești negațiunea idealului meu. Oameni pe care realitatea îi influențează cu o irezistibilă putere ipnotică, oameni pe care lanţuri de fer îi leagă de ziua de azi, - reptile cari făr'de-a fi cândva stăpâni pe situație, încremenesc în fața întâmplării, ca prada sub ochii unui şarpe. Nu simți tocmai contrarul dela ceea ce am numit - personalitate?" (Blaga, 1989: 83), într-o scrisoare datată în 1916. Încă din acest an, Lucian Blaga profilează o filosofie a socialului, care se va metamorfoza odată cu opresiunile postbelice a căror victimă va fi scriitorul. În acest caz, termenul personalitate evidențiază forța individului de a se manifesta mental și comportamental, forță suprimată, de altfel, de constrângerile sociale. Opozanții

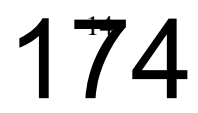


ideilor lui Lucian Blaga s-au remarcat atât publicând articole împotriva creației acestuia, cât și îndepărtându-l din funcțiile publice. Cazul Blaga-Beniuc se datorează unei ,invidii de poet” (Dorli Blaga, 2015: 47), pe care Blaga a accentuat-o prin ironiile la adresa autorului romanului Pe muche de cuțit: „,involuntară «jignire», pe care crede el că i-aș fi adus-o, e în legătură cu un cerc de cocoane. Am făcut gafa de a-i cita un vers arhicunoscut. [...] Dar eu 1am corectat nițeluș, spunând «Acesta-i poetul Mihai Beniuc/ Știe șase limbi! Dar rusește....»" (Sîrbu, 2013: 1139). Odată cu apariția Securității ca forță represivă, aceste reptile evocate de Lucian Blaga vor declasa creaţia scriitorului, utilizând false argumente cu scopul asigurării unei situaţii protejate din partea sistemului; Mihail Iubu acționează întocmai celor afirmate anterior, susținând cu vehemență că „Lucian Blaga scrie totuși și în prezent însă, așa după cum am mai arătat nu publică. Aceasta o face deoarece nu dorește să colaboreze cu regimul actual față de care are o atitudine ostilă" (Blaga, Bălu, 1999: 85). Să fie denumirea de atitudine ostilă potrivită pentru dorința scriitorului de a-și proteja opera de infiltrațiile pro-regim? Cu siguranță că Lucian Blaga își aprecia opera mai mult decât a ,accepta compromisul cu puterea care se instala, în primul rând datorită restricțiilor în ce privește libertatea în exprimare, în creație" (Dorli Blaga, 2015: 29), după cum afirmă fiica acestuia, Dorli Blaga. Se sesizează, în acest caz, o oprimare a scriitorului ca personalitate în România secolului XX. Lucian Blaga manifestă un vădit orgoliu la adresa societății înroșite și a dorinței acesteia de a-l trata aidoma unei marionete a sistemului: „Dacă sunt o personalitate, atunci să fiu considerat ca atare și tratat așa cum se cuvine unei personalități. Eu nu înțeleg să fiu personalitate numai atunci când e nevoie să fac declarații politice, iar în rest un simplu traducător"3. De asemenea, Lucian Blaga prezintă şi o slăbiciune firească a omului de litere în privința receptării și a recunoașterii propriei creații de către posteritate, afirmând: „«Toți mă veți uita, opera mea va pieri, voi muri singur, ca un câine!»” (Sîrbu, 2013: 1140). Dreptatea în căutarea căreia se află Lucian Blaga și care-i oferă, treptat, și statutul de personalitate, se evidențiază atât prin atitudinea acestuia faţă de sistemul din care face parte ca scriitor (,,eu doream să mi se dea pensia de la Fondul Literar, la care am dreptul. Dreptul și l-au obținut alți scriitori, în acest timp de când mie mi se tot răspunde că nu sunt bani. [...] Eu, ca membru al Uniunii Scriitorilor, aș avea un drept să cer ca rodul muncii mele să fie apărat. Dar vezi, asta este situația mea în țara mea. În timp ce străinii mă propun pentru Premiul Nobel - fără ca măcar să știu despre asta, Editura îmi dă certificat de traducător categoria III") (Dorli Blaga, 2015: 340), cât și vis-à-vis de propria creație, autorul Poemelor luminii apelând la discreția și la cunoștințele propriei fiice: „De altfel cariera ta peste doi-trei ani va fi una singură: să administrezi

3 http://www.romlit.ro/index.pl/o_declaraie_inedit_a_lui_lucian_blaga, articol de Ilie Rad, $O$ declarație inedită a lui Lucian Blaga, nr. 30/2012, data accesării: 22 octombrie 2018, 15:43.

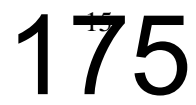


bine toată proprietatea mea filozofică, literară, teatrală. Vei putea trăi mai bine după aceasta, decât cu un salar de profesoară” (Dorli Blaga, 2015: 44).

Aprecierea care i se cuvine lui Blaga la nivel social provine din intervenția Regelui Carol al II-lea în numirea acestuia ca membru al Academiei Române; deferența cu care îi este înfățișată atât opera, cât și propria imagine îl măgulește și încântă pe scriitor, fapt care nu constituie decât unul din motivele pentru care va fi contracarat de adversarii literari și politici. Preluate din Analele Academiei și transpuse în lucrarea lui Ion Bălu, Viaţa lui Lucian Blaga, afirmațiile Regelui evidențiază și clasifică atât creația scriitorului, cât și statutul său în literatura română: „Am mai ținut să asist la această recepție pentru că ea are o mare însemnătate: Academia primește în sânul ei pe primul reprezentant al talentelor literare românești de după război. Recepția lui Lucian Blaga la Academia Română este consacrarea oficială și definitivă a literaturii actuale românești” (Bălu, 1996: 59). Recunoscut ca personalitate a României interbelice, Lucian Blaga nu se va bucura îndeajuns de gratitudinea apropiaţilor, declinul fiindu-i asigurat de schimbarea regimului şi, mai ales, de înlăturarea sa de la catedra Universității din Cluj. Așadar, atât opera, cât și imaginea distinsă pe care le afișează Lucian Blaga vor fi prejudiciate de Securitate: Blaga va fi acuzat de naționalism extremist odată cu studierea atentă și, implicit, eronată a capitolelor Spațiul mioritic și Orizont și stil. Ca replică dată falselor afirmații ale oponenților scriitorului, Dorli Blaga se focalizează asupra preocupărilor trans-naționale ale scriitorului, susținând că: ,ar fi bine să se remarce respectul și admirația lui pentru culturile tuturor popoarelor şi etniilor” (Dorli Blaga, 2015: 221). Dosarul de Securitate „Lucian Blaga", pe lângă faptul că se află redactat într-un agramatism nedemn de un asemenea serviciu al statului, evocă şi o serie de erori evenimențiale, precum trecerea în ilegalitate a Cercului Literar de la Sibiu; astfel, se consideră că după desființare, „membri acestui cerc printre care și Blaga Lucian șau ${ }^{4}$ continuat activitatea lor în mod ilegal sub forme de ședințe la care participau foști politicieni, maniști, liberali, etc, ședințe care erau urmate de dans, chefuri, etc" ${ }^{, 5}$ (Blaga, Bălu, 1999: 59). În contextul vremii, aceste dansuri, chefuri sunt false argumente care au scopul diminuării imaginii de personalitate a lui Lucian Blaga prin conturarea portretului de dușman al poporului, imagine recurentă în memoriile fiicei. Dorli Blaga confirmă în Tatăl meu, Lucian Blaga amiciția dintre Blaga și cerchiști, însă nu precizează niciun aspect care să-l condamne pe scriitor. De altfel, autoarea clarifică rolul lui Blaga în cadrul Cercului Literar de la Sibiu, afirmând: „Cerchiștii, ca grupare, nu s-au lăsat patronaţi de nimeni și s-au menţinut de la constituire independența. Blaga a fost întotdeauna invitat al Cercului” (Dorli Blaga, 2015: 219). Într-o scrisoare

\footnotetext{
${ }^{4}$ Precum apare în Dosarul de Securitate

5 Ion Bălu, Deschiderea «dosarului de acțiune informativă» împotriva lui Lucian Blaga-20 decembrie 195, II. Conținutul pe scurt al materialelor compromițătoare.
} 
din anul 1953 se reliefează profilul scriitorului deznădăjduit, posesor al unei personalități puternice, sugerate de curajul cu care își solicită drepturile: „Spune-le că, dacă nu mi se dau condițiile necesare de lucru (avansul), eu pur și simplu nu mai lucrez, căci n-am posibilitatea să lucrez. Voi considera contractul reziliat. Trebuie să le vorbești cu hotărâre. Nu pot admite să-și bată joc de mine" (Dorli Blaga, 2015: 328). Familia Blaga nu dezvoltă capricii mondene ci, mai mult, se dovedește a fi rezervată în privința prieteniilor, cauza fiind și faptul că „Tatăl meu se simțea urmărit și nu ar fi riscat să țină întruniri la el acasă" (Dorli Blaga, 2015: 220). Referindu-se și la Cornelia Brediceanu în elucidarea acestei situaţii familiale, autoarea susține că: „Personalitatea Tatălui meu o captiva în așa măsură, încât nu simțea nevoia altor relații de prietenie" (Dorli Blaga, 2015: 35).

Nominalizarea la Premiul Nobel din anul 1956 conduce la o situație defavorabilă în ceea ce privește poziția scriitorului și interesele regimului; Dorli Blaga mărturisește că evenimentul, deși „,a iritat grozav și nu a avut asentimentul oficialităţilor comuniste din România" (Dorli Blaga, 2015: 203), a oferit recunoașterea internaţională a filosofului. Totodată, efasarea traiectoriei către aprecierea occidentală- act uneltit de Președintele Uniunii Scriitorilor, Zaharia Stancu, îl determină pe Lucian Blaga, ca în toamna anului 1956, să ofere un ultimatum instituției prin intermediul unei epistole adresate fiicei sale: „Dacă până la 31 decembrie nu mi se rezolvă chestiunea pensiei îmi voi da demisia din Uniunea Scriitorilor. Fiindcă nu mai sunt dispus să privesc cu brațele încrucişate - la această nepăsare, ce mi se arată, când e vorba de rodul unei vieți” (Dorli Blaga, 2015: 340). În ceea ce privește propunerea lui Blaga pentru Premiul Nobel, Gheorghe Grigurcu, în articolul Blaga în amurg, susține că: ,indiscutabil, acordarea faimosului premiu, ar fi reprezentat o glorificare nu doar a bardului nostru, ci și a întregii literaturi

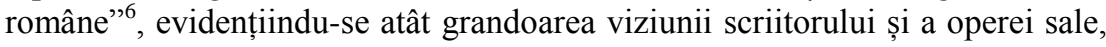
cât și șansa poporului român de a se afirma în Occident. Prin intermediul scrisorilor şi, implicit, prin relatările Corneliei Brediceanu și ale lui Dorli Blaga, se remarcă puternice contururi ale personalității lui Lucian Blaga, ale creației acestuia și, mai ales, ale societății secolului XX. Orgoliul scriitorului este susţinut de superioritatea gândirii sale, fapt care a condus și la indignarea organelor represive ale statului prin refuzul publicării unor opere multașteptate. De altfel, această superioritate a scriitorului reiese și din recunoașterea valorii personale, a viziunii auctoriale autentice, scriitorul însuși mărturisind într-o scrisoare adresată lui Vasile Băncilă: „E curios că întâia oară am un sentiment neîncercat încă: îmi devin parcă un personaj transparent. Sunt pe urmă eu însumi impresionat de latențele și virtualitățile gândirii mele! Și simt parcă o vină: vina că nu dezvolt îndeajuns eu însumi toate posibilitățile.

\footnotetext{
${ }^{6}$ http://www.romlit.ro/index.pl/blaga_n_amurg, articol de Gheorghe Grigurcu, Blaga în amurg, nr. 32/2006, data accesării: 21 octombrie 2018, 19:21.
} 
Dar sunt mânat veșnic spre noi idei, cari sper să fie nu mai puțin pline de virtualități, ca și celelalte de până aici” (Blaga, 1989: 26). În ceea ce privește orgoliul lui Lucian Blaga, acesta este remarcat și de autorul Florilor de mucigai, a cărui afirmație este citată în cea de-a doua parte a articolului lui Gheorghe Grigurcu: „«Blaga e un poet mare, păcat că e prea plin de sine»”7. De altfel, orgoliul scriitorului în universul socio-cultural se estompează odată cu apariţia crizei familiale, marcate de posibilitatea ca Tudorel, nepotul acestuia, să fie privat de prezența lui Dorli: „Devenise copilul obiect de constrângere împotriva lui Blaga? [...] «Să nu-ți faci griji, să te liniștești, eu pentru acest copil fac orice, chiar și scriu...» Prin asta se înțelegea că ar scrie cum i se cere" (Dorli Blaga, 2015: 52). Acest sacrificiu, deși pare a suprima prestigiul scriitorului, are rolul de a evidenția calitatea de familist a acestuia. Dorli Blaga reușește să prezinte câteva dintre lipsurile pe care Lucian Blaga, alături de Cornelia Brediceanu, le-au suportat în vedere asigurării unei educații calitative tinerei: ,în sărăcia noastră, după ' 47 , s-a chinuit mult pentru mine, și asta chiar în secret de Tata uneori. Trimitea la talcioc să se vândă tot ce se putea vinde numai ca să fac eu limbi străine, de exemplu. A insistat și mi-a dat, prin asta, ceva extraordinar. Pentru că, în felul acesta, eu am avut acces în trei culturi măcar, fără traduceri” (Brediceanu, 2016: 164). Totodată, aceste lipsuri ale familiei construiesc firea modestă a tinerei Dorli Blaga, care nepoziționându-se sub umbra de aur a Tatălui, a suportat consecințele renumelui său. Privind situația din secolul actual, se recunoaşte incorectitudinea și absurditatea sistemului politic, practica respingerii marilor valori în favoarea acestor reptile lipsite de personalitate, înfățișate de militanții pro-regim. Anularea sentimentului de proprietate despre care amintește Dorli Blaga în Tatăl meu, Lucian Blaga, desemnează conștientizarea importanței unui vast bagaj intelectual: ,în afara grădinii de la Bistrița, noi nu am avut casă în care să locuim, am fost întotdeauna chiriași. Iar ce au mai avut părinții mei, au vândut imediat după război, aproape pe nimic, ca să putem trăi” (Dorli Blaga, 2015: 142).

Interesat de diferite domenii de studiu, poliglot și autor al unei vaste creații incluse atât în istoria literaturii române, cât și în cea europeană, construcția interioară a lui Lucian Blaga se dovedește a fi în contrast cu cea a Corneliei Brediceanu. Dorli Blaga, în memorii, reconstituie portretul părinților, focalizându-se asupra conturării imaginii tatălui răbdător, dedicat familiei și, mai ales, propriei creații. De altfel, în scrisorile adresate Corneliei Brediceanu, Lucian Blaga evidențiază ipostaza în aşteptare a omului pândit de consecințele hazardului: „Nu afli că în unele scrisori sunt foarte liniștit? Crede-mă, eu însumi îmi simt mare această liniște. [...] e o liniște pândită de furtună, mare, tocmai pentru că în fiecare moment pot să se dezlănțuiască fulgerele" (Blaga,

\footnotetext{
${ }^{7}$ http://www.romlit.ro/index.pl/blaga_n_amurg_ii, articol de Gheorghe Grigurcu, Blaga în amurg, II, nr. 33/2006, data accesării: 22 octombrie 2018, 14:32.
} 
1989: 92), ceea ce contrasează cu dinamismul lăuntric al soției. Aceasta, în ipostaza de iubită, deține un caracter impulsiv, sugerat de gesticulația expusă de Lucian Blaga în scrisori: „mi-ai zis odată: «Așa-mi vine să-ți arunc paharul în cap» - şi m-ai privit atât de viu, de sălbatec, de adânc - încât mi s-a zguduit templul din temelii şi m-am gândit «ecce homo!»" (Blaga, 1989: 88). În Tatăl meu, Lucian Blaga, autoarea folosește doar apelativul de "Mamă” în desemnarea Corneliei Brediceanu, neutilizând, astfel, numele întreg al acesteia, ceea ce sugerează și o discrepanță profesională între cei doi părinți. De altfel, Dorli Blaga prezintă și natura relaţiei sale cu Cornelia Brediceanu: „ea nu era o tandră [...] eu nu am amintiri cu ea în care să mă mângâie, să mă sărute... [...] Era o mamă extraordinar de corectă, tot ce-a făcut a făcut foarte bine" (Brediceanu, 2016: 163). Ca revers al acestui comportament matern, în capitolul Corespondență de familie comentată, Dorli Blaga conturează ataşamentul față de Lucian Blaga, evocând cadrul copilăriei și, implicit, al jocului de familie, numindu-și părintele: Tăticu, Tati, Tai-Tai-Tai, Uci, Ucităt ,încercam să citim cuvintele pe dos. Astfel «tăticu» devenea «Ucităt». Prescurtat «Uci»» (Dorli Blaga, 2015: 320).

\section{"«Mi-am încheiat sistemul, acum pot să mor»"8}

În Aforisme și însemnări, relația Creație-Iubire este analizată atât în mod colectiv, cât și în mod individual, cele două elemente fiind identificate ca „pasiuni cari se leagă și se condiționează reciproc, într-un fel care nu este și al altor pasiuni. [...] E un semn de feminitate să pui accent suprem pe iubire, și un semn de bărbăție să-l pui pe creație" (Blaga, 1977: 160). De altfel, resortul interior al scriitorului în elaborarea Trilogiei se datorează conexiunii dintre Creație și Dorli, cele două elemente decisive în desemnarea progresului literar al acestuia : „Lucian se gândește cu multă satisfacție că a început sistemul său filozofic, cu Eonul dogmatic, în anul când s-a născut Dorli, iar când va împlini Dorli 7 ani va termina și cu al șaselea volum al sistemului. [...] Sistemul nostru filozofic crește paralel cu Dorli, «cum mi-a crescut sistemul» - zice uneori Lucian, glumind, când o vede pe Dorli ce mare s-a făcut" (Brediceanu, 2016: 50). Totodată, prin intermediul corespondenței și al memoriilor se stabilește atât profilul scriitorului, cât și cadrul în care opera acestuia este concepută. Lucrând în birou ori în natură, creația lui Blaga este mereu pătrunsă de o frenezie a spiritului, de o obsesie a materializării propriei filosofii. Cornelia Brediceanu, consemnând în propriul jurnal data de 25 septembrie 1937, descrie febrilitatea cu care scriitorul se lasă pradă inspirației și energiei creatoare: „Lucian a terminat azi întâia redactare a volumului său Artă şi valoare. Acum două săptămâni nici nu se gândea să-1 înceapă. Dintr-odată s-a hotărât și s-a apucat de lucru. În douăsprezece zile de muncă încordată, în medie 5 ore pe zi,

\footnotetext{
${ }^{8}$ Dorli Blaga, Tatăl meu, Lucian Blaga, Editura Humanitas, București, 2015, p. 47.
}

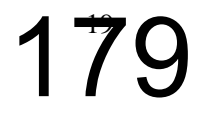


a scris întreg volumul, 178 pagini mari” (Brediceanu, 2016: 95), sugerându-se, de altfel, un talent și o tehnică scriitoricească pe deplin formată. Totodată, întro scrisoare adresată Corneliei Brediceanu cu un an înaintea publicării Poemelor luminii, Lucian Blaga atribuie acestei modalități de scriere un conturat destin poetic, scriitorul susținând: „Încep să cred eu însumi că sunt poet. Și-o să mă desăvârșesc încetul cu încetul și în tehnică formală" (Blaga, 1989: 134).

Actul creației îl stăpânește pe Lucian Blaga, care împrumută din experiențele private ale surorii sale, Letiția, în conturarea personajului eponim din Daria; Dorli Blaga, de altfel, admite şi accentuează firul biografic din interiorul creației scriitorului : „atunci când era vorba de creația lui, Tata nu prea ținea seama nici chiar de familie" (Dorli Blaga, 2015: 273). Totodată, însuși scriitorul clarifică, într-o scrisoare adresată lui Vasile Băncilă, importanța raportului viaţă-operă, accentuat de ipostaza creației ca refugiu: „În fond am avut o viață grea, cu luminișuri din când în când. M-am refugiat totdeauna în operă" (Blaga, 1989: 29).

O altă obsesie a scriitorului, dezvăluită de Dorli Blaga, constă în teama preluării de idei poetice şi filosofice de către contemporanii săi, Lucian Blaga fiind ,perfect conștient că imaginile, metaforele, chiar versuri întregi se pot fura (fie și neintenționat, de către un poet). De aceea el se ferea ca textele lui inedite să circule în lumea literară” (Dorli Blaga, 2015: 204). De altfel, și în volumul de Corespondență se remarcă cerința scriitorului ca propria creație să fie secretizată: „Manuscrisul, te rog să nu-1 mai arăţi nimănui!!! Și să-i păstrezi secretul!”, susține Lucian Blaga într-o scrisoare către Oscar Walter Cisek, datată în anul 1925. Această obsesie reiese, mai ales, în scrisorile adresate Corneliei Brediceanu; scriitorul evocă, mai întâi, argumentul că nu deține nicio copie a poemelor trimise, reliefându-se, totodată, și o îmbunătătire a propriei tehnici: „Poemele în proză cele vechi - mi-ar părea bine să faci focul cu ele. [...] Cele în versuri ce ți le trimit să le grijești bine, fiindcă eu nu le am scrise deloc" (Blaga, 1989: 135). De asemenea, Blaga împărtășește viitoarei soții, încă înainte de a publica Poemele luminii, neliniștile care-1 stăpânesc continuu și care aparțin aceluiași univers auctorial: „Numai de ceva mi-e grozav de teamă: să nu-mi arate cumva poemele cuiva să-mi fure ideile!” (Blaga, 1989: 152) susține scriitorul referindu-se la Sextil Puşcariu. Acest mijloc de prevenire conturează atât un orgoliu al creatorului, cât și o neputință a acestuia de a-și proba propria operă - respectivele creații nefiind publicate.

În volumul Tatăl meu, Lucian Blaga, între scriitor și opera creată pare a se fi realizat o conexiune plasată sub semnul unei datorii, odată cu încheierea sistemului filozofic, în 195: „Mi-am încheiat sistemul, acum pot să mor". Această finalitate a ființei legate de propria operă prezintă profilul scriitorului dedicat atât actului creației, cât și posterității, întrucât Lucian Blaga redactează până și un Testament editorial, prin care justifică schema noului

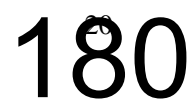


plan al Trilogiilor. Totodată, această accepțiune a thanatosului este sugerată de Blaga în aceeași scrisoare adresată lui Vasile Băncilă în care atribuie creației rolul de refugiu; scriitorul, însă, copleșit de suferința soției, găsește în operă o recuperare a propriului echilibru interior: „Am crezut că n-o să mai scap teafăr din acea situație! Pe urmă încetul cu încetul ne-am refăcut. De multe ori am voit să scap trăgându-mi un glonte. Numai grija fetiței m-a salvat" (Blaga, 1989: 29).

Dorli Blaga în cartea sa încearcă o reconstituire a imaginii părintelui demn, dedicat atât familiei, cât și propriei creații, autoarea apelând atât la elemente biografice în conturarea portretului tatălui și scriitorului Lucian Blaga, cât și la elemente autobiografice, care oferă volumului puternice note memorialistice. Totodată, existența scrisorilor ca mărturii ale evenimentelor şi, implicit, ale trăirilor poetului evidențiază personalitatea și conduita acestuia și întăresc profilul mai puțin cunoscut, reconstituit, al îndrăgostitului, al tatălui și al scriitorului Lucian Blaga. Astfel, Corespondenţa de familie publicată de Dorli Blaga, Jurnalele Corneliei Brediceanu şi volumul de Corespondenţă, publicat în 1989, alcătuiesc opere veritabile în conturarea monografiei Lucian Blaga, dincolo de poziția pe care Trilogiile i-o conferă în literatura română şi europeană, și dincolo de imaginea pe care aliaţii regimului reușesc să i-o creeze în rapoartele pentru Securitate și în presa vremii.

\section{Bibliografie}

Bălu, Ion, Viața lui Lucian Blaga, vol. II, București, Editura Libra, 1996. Blaga- Brediceanu, Cornelia, Jurnale. 1919, 1936-1939,1939-1940,1959-1960, București, Editura Humanitas, 2016.

Blaga, Dorli, Bălu, Ion, Blaga supravegheat de Securitate, Cluj-Napoca, Biblioteca Apostrof, 1999.

Blaga, Dorli, Tatăl meu, Lucian Blaga, București, Editura Humanitas, 2015. Blaga, Lucian, Corepondența (A-F), Cluj-Napoca, Editura Dacia, 1989.

Blaga, Lucian, Elanul insulei, Cluj-Napoca, Editura Dacia, 1977.

Grigurcu, Gheorghe, Blaga în amurg, II, nr. 33/2006, http://www.romlit.ro/index.pl/blaga_n_amurg_ii, 22 octombrie 2018.

Grigurcu, Gheorghe, Blaga în amurg, nr. 32/2006, http://www.romlit.ro/index.pl/blaga_n_amurg, 21 octombrie 2018.

Rad, Ilie, O declarație inedită a lui Lucian Blaga, în România literară, nr. 30/2012,

http://www.romlit.ro/index.pl/o_declaraie_inedit_a_lui_lucian_blaga, 22 octombrie 2018.

Sîrbu, D. Ion, Jurnalul unui jurnalist fără jurnal, București, Academia Română, Fundația Națională pentru Știință și Artă, 2013. 